\title{
A experiência do fora em Bang Bang:
}

\section{Os movimentos erráticos no cinema menor de Andrea}

\section{Tonacci}

\section{Por Auterives Maciel Júnior e Amanda Souza Ávila Lobo}

Em um filme voltado para a exposição de encontros fragmentados, de sequências sustentadas no tempo da duração real, de momentos plenos de signos óticos e sonoros dispostos pela divergência e da profusão de uma trilha que faz da dissonância o tom fundamental da banda sonora; os movimentos erráticos podem ser entendidos como o procedimento que orienta essa narração cinematográfica tonacciana, tornando possível a experiência do ato de pensar. Mas como podemos nomear esse modo de pensar engendrado pelos movimentos erráticos, cujo nomadismo cinematográfico constitui o seu conteúdo? E como conceituar o cinema que expressa o pensamento deflagrado pelos movimentos erráticos deste filme? Em primeiro lugar, nomearemos esta forma de pensar desmedida, como um pensamento experimental efetuado na ruptura com a realidade determinada; em seguida, definiremos tal procedimento fílmico por intermédio daquilo que aqui conceituaremos como um "cinema menor". Com a explicitação dessas duas questões, construiremos a argumentação explicativa das derivas fílmicas de Andrea Tonacci em Bang Bang, filmado na década de 1970, de modo a apresentar sua força metamórfica de problematização radical e construção revolucionária da realidade.

De antemão, é preciso frisar que o movimento errático não é um derivado do erro. Na esfera filosófica ele é, ao contrário do que diz a doxa ${ }^{1}$, aquilo que torna o pensar possível. Se admitirmos, provisoriamente, que o ato de pensar supõe o desvio na sua determinação, é quase conveniente situar os movimentos erráticos como estando na gênese da sua produção. Sendo assim, uma breve

\footnotetext{
1 Doxa é a definição filosófica da reta opinião, formada, segundo Deleuze, pelo bom senso e pelo senso comum. Esses dois elementos constituem a forma de uma imagem dogmática do pensamento baseada no modelo da recognição no qual a verdade de um objeto pode ser alcançada por exercício de adequação e verossimilhança, se desvencilhando dos sentidos, que levariam ao equívoco desse caminho. De modo contrário, para Deleuze, não há caminho originário a ser seguido pelo pensamento, pois ele só se dá a partir de um choque fortuito com um signo insólito que lhe coloque em movimento. A esse respeito consultar o livro do Gilles Deleuze (1988) Diferença e Repetição, ao longo do capítulo três "A imagem do pensamento".
} 
conceituação é necessária para o entendimento daquilo que deveremos ao longo do ensaio explicitar: os movimentos erráticos são a fundação material de um pensamento que se exerce no vetor de uma desterritorialização ${ }^{2}$ absoluta; isto é, no vetor de um movimento que deflagra o caos fazendo nascer o ato de pensar no seio do próprio pensamento. Dito de outra maneira, os movimentos erráticos são aqueles que expressam um pensamento desmedido que se ergue por meio do caos, mas se coloca em combate contra sua esterilidade, advindo de uma fuga inusitada dos territórios habituais e sedentarizados da opinião. Contra os zelos da opinião coloquial, existe o movimento errático que conduz o pensamento nos labirintos dos acasos e das repetições. No nomadismo dos espaços urbanos apresentados em Bang Bang (1971), eis uma linha errática contaminando o procedimento fílmico.

Aprofundando a primeira questão, diremos que a vocação nômade desse filme - com a sua audácia audiovisual - expressa um modo de pensamento determinado pelos acontecimentos resultantes de encontros fragmentados, de acasos afirmados e de desvios apontados pelas perambulações fílmicas. Trata-se de um pensamento determinado pelas experimentações que engendram a condição efetiva do surgimento do ato de pensar por intermédio de encontros desviantes proporcionados por movimentos erráticos. Nesse contexto, pensar se configura como um acontecimento que emerge da relação do pensamento com forças oriundas de um campo experimental, que se encontra fora da dimensão representativa, de tal modo que podemos dizer que esse empreendimento se configura como um ato de pensar nomeado como pensamento do fora.

Mas qual o significado preciso dessa nomeação? Significa dizer que as forças que engendram os acontecimentos díspares no seio do pensamento forçam-no a pensar no mundo fora da realidade já determinada, haja vista colocá-lo em relação com aquilo que lhe é estranho e, portanto, que se mostra fora da sua zona de reconhecimento. Aqui, a aventura do pensamento deve ser analisada segundo uma orientação intempestiva, onde uma experiência limite do ato de pensar se estabelece a partir de momentos críticos da existência, onde as forças que se apossam do sujeito impõem ao pensamento uma problematização criativa da vida. Ora, é nessa experiência

\footnotetext{
2 Termo ligado à geofilosofia deleuziana e guattariana em que se estabelece que o pensamento não se dá nas categorias do sujeito e do objeto, mas nas de terra e território. Por seu turno, território é aquilo que possui propriedade ontológica. O trabalho do pensamento é estabelecer cortes naquilo que se encontra estratificado e enraizado territorialmente, buscando desterritorializar e criar novas condições de reterritorialização.
} 


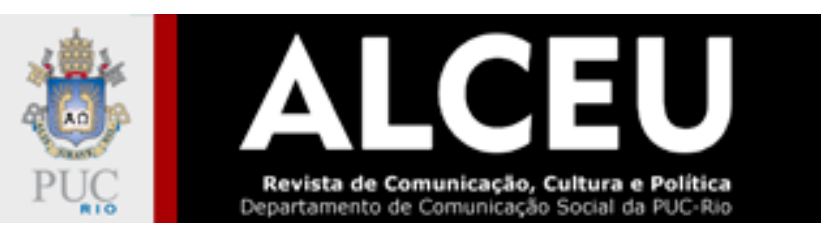

singular que 0 ato de pensar cria a diferença, pois se determina como uma potência das experiências vitais.

No mundo contemporâneo encontramos autores que não param de confirmar esta experiência do fora. Exigem de direito uma repartição severa entre pensar e representar, apresentando a atividade do pensar como uma criação singular. Posicionados contra a ortodoxia da razão, afirmam os direitos de um pensamento disruptivo, onde a atividade do pensar já não pertence mais a um sujeito dotado de interioridade e voltado para a reflexão. Propõem, então, a existência de contra-pensamentos, "cujos atos são violentos, cujas aparições são descontínuas, cuja existência através da história é móvel" (DELEUZE \& GUATTARI, 1997, p. 46). Insistem na determinação ética de um pensar singular que se atualiza em uma experimentação combativa, se insurgindo contra as opiniões e os dogmas morais que recaem sobre o pensamento quando este é avaliado segundo as forças dos poderes estabelecidos.

Segundo Foucault (1988), o pensamento do fora proposto por tais autores pode ser devidamente esclarecido no combate contra a interioridade de um pensamento universal representado por um sujeito. Nessa nova inflexão não pensamos no elã de um gosto ou de uma boa vontade. Pensamos quando somos forçados, pois pensar tornou-se uma mera possibilidade cuja realização passa a depender de uma violência proporcionada por uma ocasião, violência esta que se exerce sobre o pensamento, tornando-o ativo e criador. Mas qual a experiência do fora que faz advir o pensar ao pensamento? Para Foucault as respostas se multiplicam de acordo com a variedade dos procedimentos. Assim, "a atração é para Blanchot o que, sem dúvida é, para Sade o desejo, para Nietzsche a força, para Artaud a materialidade do pensamento... para Bataille a transgressão" (FOUCAULT, 1988, p. 18) e, em nosso entendimento, para esse nosso caso, os movimentos erráticos do filme Bang Bang, engendrados por Tonacci.

No cinema, consoante Deleuze (1985), o pensamento do fora se afirma por meio de filmes que não almejam uma encenação representativa, seja ela orgânica ou dialética, devidamente circunscrita pela ambição de proporcionar ao espectador uma imitação da realidade. Nesses termos, não há em tais filmes nenhuma tentativa de construir, por intermédio da montagem, uma ideia cinematográfica de uma totalidade representacional, ainda que aberta, porém restrita à ambição de descrever veridicamente a realidade de uma situação configurada por intermédio de uma encenação realista e/ou naturalista. Assim, o domínio da representação, tão caro aos filmes de imagem-ação, é cinematograficamente sabotado por planos-sequências que desfazem a 
cadência orgânica, em proveito de uma descontinuidade fílmica que introduz a experiência do fora no todo do filme, o que em Tonnaci se evidencia pelos cortes irracionais que quebram com as sequências lógicas dos planos cinematográficos.

Ora, há, por um lado, em Tonacci um pensamento do fora consistindo na descrição, na narração e na narrativa ${ }^{3}$, que, ao introduzir o elemento do improviso, tangencia uma irracionalidade fílmica e rompe com a pretensão realista de cumprir os protocolos de um cinema verdade. Por outro lado, Tonacci faz um filme experimental que assume o risco de filmar um pensamento vivo, transposto concisamente no intercurso dos seus fragmentos surgidos dos acasos dos encontros com forças oriundas do seu fora (dehors), colocando o ato de pensar na dimensão do impensável nascido das experimentações erráticas que conduzem a produção fílmica. Nessas derivas experimentais temos um cinema nômade não circunscrito no universo das representações. Ou seja, um cinema com a intenção de problematizar a realidade estabelecida, contrariando a vocação dogmática de fazer da representação o lema majoritário do pensamento.

Cabe aqui detalhar um pouco mais um outro aspecto desse pensamento do fora dizendo que nele, $\mathrm{o}$ ato de pensar se engendra no cerne do próprio pensamento, havendo neste uma fissura central que testemunha pela inexistência de uma plenitude de um ser pensante, descrito por Descartes na aurora da representação moderna. A esse respeito, comentando a experiência do pensamento descrita por Artaud e tecendo as considerações cinematográficas de tal relato, o que Deleuze vai afirmar sobre a relação do pensamento com as forças oriundas do fora nos parece exemplar. Nas considerações cinematográficas feitas por Artaud o que este tipo de cinema deve privilegiar não é a força do pensamento, mas o seu "impoder":

[...] e o pensamento nunca teve outro problema. Isso é, justamente, muito mais importante que o sonho: essa dificuldade de ser, essa impotência no cerne do pensamento. Isso que os inimigos do cinema censuram nessa arte [...] para Artaud se torna a glória sombria e a profundidade do cinema. Com efeito, para ele, não se trata de uma mera inibição que o cinema nos traria de fora, mas da inibição central, do desmoronamento e da petrificação interiores, do "roubo dos pensamentos" do qual o pensamento nunca deixa de ser vítima e agente (DELEUZE, 2013, p. 201, grifos do autor).

Assim, ao acreditar no cinema, Artaud o considera essencialmente capacitado a revelar essa impotência de pensar que se encontra no seu cerne. Todavia, é dessa impotência, ou impoder, que

\footnotetext{
${ }^{3}$ Essas três instâncias são trabalhadas por Deleuze na obra $A$ imagem-tempo (1985), quando analisa a potência do falso no cinema. Relacionam-se a construção cenográfica, dos personagens, relação diretor, obra e espectador, que imbricam, no cinema moderno que traz a imagem-cristal, o real e o imaginário, o falso e o verdadeiro, o objetivo e o subjetivo.
} 


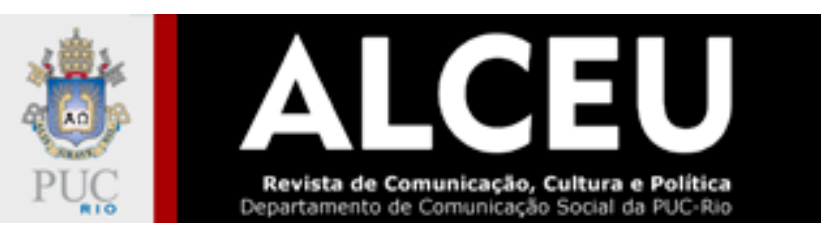

surge a possibilidade de pensar como um acontecimento oriundo do encontro da força do pensamento com forças advindas da experimentação.

Que temos, portanto? Um filme feito pela experiência que procura descrever movimentos e evocar a potência de personagens bastardos, contemplados na apresentação de um povo que inexiste, visando preencher as lacunas deixadas pelo devir das minorias marginais. Um filme construído nos espaços nômades de uma cidade aberta e povoada pelos movimentos erráticos de desterritorialização. Assim, a experiência do fora em Bang Bang se configura pelas derivas entrevistas nas passagens dos seus longos planos-sequências que não compõem uma totalidade orgânica pelo exercício da montagem. Bang Bang é a expressão revolucionária de um procedimento construído por personagens menores que evoca de modo inusitado as minorias silenciosas e nômades de uma cidade aberta às multidões. Ademais, por ser um filme realizado com poucos recursos financeiros, que explora a potência de imagens em ângulos restritos, desenvolve os elementos irracionais de um filme feito para minorias aptas a construírem um devirrevolucionário. Sendo assim, não constitui exagero dizer que esse filme de Andrea Tonacci é a expressão cabal de um cinema menor, entendendo essa adjetivação como uma orientação política que define, com propriedade, os procedimentos cinematográficos construídos por pensamentos consagrados à expressão de uma minoria nômade em pleno devir.

Entendemos que cinema menor é o conceito de filmes que não aderem ao populismo majoritário daqueles feitos para os olhares da maioria. Antes, ele se define na contramão dos filmes com conteúdos políticos implicados na orientação de consolidar a realidade estabelecida, propondo, em contrapartida, os movimentos erráticos que externam o devir de uma minoria através de personagens não comprometidos com os modelos padronizados pelo cinema realista e comercial. Nestes termos, conforme veremos mais detalhadamente, Bang Bang é um filme menor de Andrea Tonnaci, que conjuga a expressão potente do pensamento do fora com a atitude minoritária dos seus estranhos e pungentes personagens.

Aqui, convém acrescentar que o pensamento do fora de um cinema menor são tentativas conceituais que definem uma política e uma estética livremente inspiradas em propostas já feitas por Gilles Deleuze e Félix Guattari em outros domínios artísticos e filosóficos. Destarte, na obra intitulada Kafka, por uma literatura menor (1975), Deleuze e Guattari definem a literatura de Kafka como um procedimento minoritário que consiste, precisamente, no uso menor que um escritor faz de uma língua maior com o propósito de arrancá-la dos seus sulcos coloquiais. Os autores 
assumem, deliberadamente, o vetor minoritário dessa literatura, contrapondo-a às ditas literaturas maiores ou democráticas, mostrando o estilo político e revolucionário dos seus procedimentos. Assim, menor qualifica, por exemplo, o devir de um escritor que subverte os valores estabelecidos ao escrever para minorias em uma língua estrangeira inventada pelo tratamento minoritário dado à língua supostamente padrão; qualifica, igualmente, a vocação de uma literatura que insere o caso individual imediatamente na esfera política; e qualifica, enfim, a desterritorialização absoluta alcançada pelo procedimento criador do escritor.

Em um outro texto dedicado a Carmelo Bene, intitulado Um manifesto de menos (1979), Deleuze irá tratar de um teatro menor no procedimento dramatúrgico desse autor singular. No novo contexto, menor qualifica a invenção de um teatro construído na ambição de amputar das peças tradicionais todos os elementos majoritários e de poder que habitam a representação teatral. Aqui, a encenação teatral consiste em desenvolver as virtualidades de uma peça que vigora graças à eliminação dos personagens que representam o estado e as soberanias estatais. No teatro menor os autores constroem um manifesto de menos, buscando os elementos minoritários que habitam as invenções artísticas revolucionárias.

Já no Mil Platôs vol. 5, os autores Deleuze e Guattari irão falar de um uso menor da língua, em uma ciência nômade ou menor, estabelecendo uma conexão entre tais termos e a experiência do fora. Tal empreendimento pode ser explicitado em páginas brilhantes do platô intitulado Tratado de nomadologia: a máquina de guerra, no qual o pensamento nômade conjuga a experiência do fora com os procedimentos filosóficos minoritários.

Sendo assim, quando aqui falamos de um cinema menor, queremos, com essa expressão, enaltecer o cinema de Andrea Tonacci, mostrando os potentes aspectos minoritários configurados na descrição, na narrativa e na narração de Bang Bang. Nesses termos, cinema menor é a maneira como nomeamos os filmes que subvertem a lógica da representação estatal e mercadológica, apresentando a revolução - na forma e no conteúdo do enredo cinematográfico - por intermédio de devires minoritários, de movimentos erráticos, de falsos raccords, descontinuidades narrativas, usos impróprios da língua no cinema, disjunção ótico e sonora e desterritorialização na pretensão realista dos filmes feitos com a convicção de que a função do cinema é imitar a realidade. Filmes que evocam minorias apátridas, ao filmar as experiências nômades existentes nos espaços urbanos, pela exposição de personagens bastardos envolvidos em experimentações inusitadas, que acontecem no cinema graças à materialidade de imagens que conjugam o pensamento com 
experiência intensa do corpo. Cumpre acrescentar, como veremos mais adiante, que nessa inflexão o cinema menor e a experiência do fora fazem apelo a uma conexão entre o pensamento e o corpo, que a câmera cinematográfica deve apresentar através dos seus célebres planos-sequências.

Assim, as brigas patéticas que deflagram a primeira cena neurastênica no táxi que vagueia nos trajetos das ruas, acompanhada da câmera curiosa que quase como um personagem registra a balbúrdia do protagonista com o motorista, a atmosfera convulsiva de uma cidade nômade escondida no coração do Brasil, a apresentação escandalosa dos três bandidos que iniciam uma grande perambulação ainda nos créditos iniciais, a dança frenética e envolvente apresentada no alto dos prédios, a corrida sem destino do carro na estrada, a construção insólita da mise-en-scène, dos cenários, dos diálogos e dos personagens compõem os movimentos erráticos ou aberrantes ${ }^{4}$ que tremulam a câmera durante toda a trama, dando a Bang Bang um estilo insidioso de um filme sem gênero, errante e de pensamento provocativo e vago, que explode com a ditadura das imagens orgânicas.

O que será que se questiona através dessas cenas insólitas? Devemos pensar no anúncio de um ser menor ${ }^{5}$ que explora os trajetos dos espaços lisos ${ }^{6}$ citadinos? Ou não estaríamos diante de uma terra habitada pelo vetor nômade de um errante em transe urbano? Talvez o cineasta nômade - um ser menor por excelência - frequente os espaços lisos perambulando em uma cidade experimental com o intuito de explorar os meios não quadriculados de uma geografia aberta aos encontros fragmentados. Entretanto, é certa a assertiva de que Bang Bang é a expressão de um pensamento nômade que se faz com o menor e o errático na forma e no conteúdo, já que não existe guerrilha nem tampouco aventura definida pela busca da verdade, menos ainda faroeste de triunfo e busca de justiça pela coerência narrativa. Há, ao contrário, fragmentos narrativos de

\footnotetext{
${ }^{4}$ O movimento aberrante está aqui atrelado e atuando como um sinônimo do movimento errático, significando aquele que não possui centro. É o termo utilizado pelo Deleuze (1985) quando discute o cinema. Esse movimento vai se caracterizar como aquele que estabelece uma fissura na sucessão entre as imagens, rompendo com a relação entre percepção e ação, demonstrado tanto na supressão de uma única narrativa, quanto de um único personagem. Está associado, também, ao uso dos falsos raccords que estabelecerão as falsas continuidades ou os cortes irracionais. Consideramos como um movimento típico da narrativa de Bang Bang. Sobre a importância do movimento aberrante na obra de Gilles Deleuze, ver Deleuze, os movimentos aberrantes de David Lapoujade.

5 Ser menor se configura enquanto aquilo que rompe com critérios normativos e morais, considerados como moldes (o padrão/maior), trazendo configurações disruptivas. Deleuze e Guattari compreendem como modulações (o menor) as diversas maneiras de operar as variações nesse molde, de modo a promover uma incessante metamorfose, portanto, se colocar em devir. Num regime social baseado na heteronormatividade, no consumismo, na branquitude, no capacitismo, os seres menores podem ser pensados como o devir-trans, o devir-travesti, o devir-índio, o devir-negro, o devir-cigana, etc. Para uma maior compreensão acerca do conceito de devir e menor, ver Mil Platôs (1980), vols. 4 e 5.

${ }^{6}$ Mais um termo ligado à geofilosofia que significa o aberto, ontologicamente falando, possível de ser experimentado e expandido.

Em seu oposto tem-se o espaço estriado, já determinado, hierarquizado e de uso limitado.
} 
encontros que tornam visíveis o tempo em estado puro, através da neurastenia de um dos protagonistas que erra a direção para produzir o pensamento na instância formidável da experiência do fora, que, reforçamos, é, portanto, aquele que se encontra no âmbito do acontecimento, que não pode ser determinado e que, quando advém ao campo, o faz para deslocar questões, favorecendo o pensar enquanto problematizar. Desta forma, o que se segue é uma cartografia desse pensamento nômade presente em Bang Bang, observando suas configurações derivantes ou seus movimentos erráticos ${ }^{7}$ na apresentação da narração com os personagens que trazem a força antiidentitária; da descrição com seus espaços quaisquer, da narrativa e sua antiteleologia e inexplicabilidade; da multiplicidade temporal; da relação obra/espectador; da digestão nômade do diretor para construção do seu cinema menor; buscando, com isso, percebê-lo enquanto força de nomadização, capaz de promover a desterritorialização e engendrar novas reterritorializações do pensar.

\section{O errático presente na narração e na descrição: a deriva dos personagens de Bang Bang e o espaço qualquer}

O filme Bang Bang (1971), dirigido por Andrea Tonacci, já se inicia com dois personagens num carro, sem destinação e sem objetivos específicos, num diálogo perturbador, carregado de irritabilidade, que não colabora para nortear a narração, mas para causar uma estranheza ao espectador. O personagem interpretado por Pereio não confirma ao taxista para onde deseja ir, gritando e gesticulando para seguir em frente ou solicitando que realize uma curva ou um retorno quando já não mais é possível. A sequência finaliza com o taxista conseguindo expulsá-lo do seu carro quando ele tenta roubar-lhe a direção.

Após um corte, segue-se nova sequência de planos, numa cena que aborda três bandidos, um deles cego e armado que atira para todos os lados, a qualquer momento; outro que se apresenta vestido de mulher e que come compulsivamente, uma travesti gulosa; e outro que também se transfigurará numa mulher em outra sequência mais à frente. Todavia, em nenhum momento do filme eles são apresentados cometendo algum furto ou assassinato, apenas numa perseguição sem definição motivacional, trancados num quarto, ou numa fuga acelerada que não se sabe do

\footnotetext{
${ }^{7}$ Aproveitamos o ensejo para indicar a dissertação de mestrado de Adriane Maria Puresa Fonseca (2012), intitulada Os errantes do cinema marginal, na qual, sem realizar análise filosófica, ela apresenta a errância como uma característica recorrente na construção dos personagens, na narrativa e na recepção dos filmes realizados nos anos de 1960 e 1970, exemplificando dentre, diversas outras obras e cineastas, também o Bang Bang de Andrea Tonacci.
} 


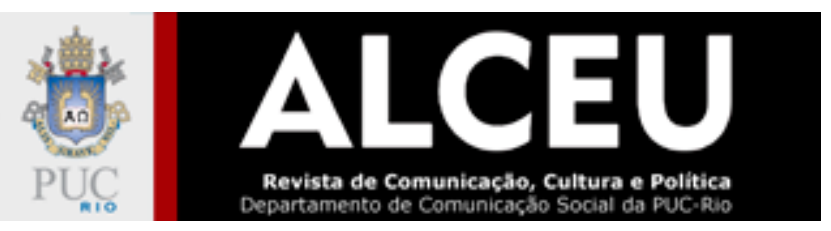

quê, de modo que até mesmo estes, considerados párias sociais, são inoperantes no filme, pois são mostrados dissociados de qualquer objetivo ou funcionalidade a ser atingida. Antes, são apresentados por sua nulidade, despropósito e inação, como que desfigurados do que aparentam ser.

Seguindo o ritmo do filme, tem-se uma mulher que transa com um homem narcísico que usa uma máscara de macaco (o mesmo ator da corrida de taxi), numa sequência quase surreal, apresentando os valores morais e sociais de modo caricato e irônico, pontuando no filme um caráter profanador e irreverente que rompe com as narrações estéticas nomeadas por Ismail Xavier (2012) por "bem-comportadas", associando o homem à sua condição mais primitiva e satirizando o cuidado com o corpo e a saúde, tomando leite de magnésia antes da cópula. Bang Bang traz, ainda, essa mesma mulher noutras sequências, realizando outras ações, sem vinculação entre si, tal como durante a dança cigana ou em companhia a Pereio durante uma conversa num bar e na perseguição de carro na estrada. Desse modo, o filme destrona a fórmula hollywoodiana de construção do enredo em torno de heróis, vilões, casais, apresentando seus personagens de modo ambíguo, duplicando-os, inclusive problematizando a narração e pulverizando sua centralidade, numa força anti-identitária que rompe com a fixidez e com qualquer parâmetro para o espectador se vincular, deixando-o também à deriva, sem ponto de ancoragem.

Além disso, Bang Bang traz seus personagens inominados, deslocados de sua significância social, desconstruindo o modelo do corpo dócil, ordenado e organizado, afeito aos serviços e poderes de estado, aqui considerado como orgânico, em prol de uma concepção de corpo mais próxima daquela compreendida por Deleuze e Guattari em Mil Platôs vol. 3, como Corpo sem Órgãos (CsO), ou seja, um corpo inorgânico, intenso, um corpo de resistência na medida em que se esquiva de qualquer tentativa de adequação ou designação finalística: pra que serve um motorista se não há caminho a seguir? Para que bandidos, se não há o que roubar? Do mesmo modo, aponta com sua descrição, espaços-quaisquer, ou seja, lugares sem espacialidade determinada, objetos sem funcionalidade: Para que um bar se não há quem comercializa? Para que um telefone que toca se não há quem o atende? Mostrando-se enquanto uma produção não pragmática, que quebra as leis de distribuição e retira a complementaridade entre os espaços hodológico e euclidiano ${ }^{8}$ do filme, de modo a não ser possível definir estados psicossociais dos

8 Deleuze discorre acerca desses espaços nas obras Imagem-Movimento (1983) e Imagem-Tempo (1985). Significam: espaço hodológico (Kurt Lewin), o espaço de tensões e oposições vividos na narração capazes de definir o comportamento dos 
personagens a partir de suas ações, já que estas não desembocam num desfecho, mas, antes, relançam as tensões, forçando a narração e a descrição a se conjugarem com uma narrativa inexplicável. Com isso, o filme apresenta um caráter revolucionário desse CsO atrelando-o a um aspecto antiteleológico, já instaurado pela filosofia nietzschiana que alia a luta contra a finalidade à luta contra a metafísica e a moral. Sobre este aspecto, diz Nietzsche (2006, p. 77) que a "luta contra a finalidade é sempre luta contra a tendência moralizante na arte, contra a sua subordinação à moral”. Quanto a este ponto, Xavier (2012) frisa o fato do filme ser da década de 70, momento em que o país se via numa conjuntura de difícil estreitamento dos laços entre política e estética, com o estabelecimento do Ato Institucional no 5 (Al-5), que dificultou sobremaneira a liberdade artística, afirmando uma tensão maior entre convenções e rupturas, entre arte industrial e autonomia criativa, destinando ao artista marginal a possibilidade da transgressão e do atravessamento das fronteiras, por meio da violência agressiva na experimentação e na provocação comportamental, fatores muito presentes em Bang Bang.

Com toda essa criação, o filme rompe com critérios da descrição bem demarcada e adequada à narração para produção de cunho realista de uma noção de verdade, de um mundo verdadeiro e de um homem verídico, se aproximando da produção de uma fabulação que desaprisiona a arte dos clichês quando ela se objetiva como uma causa para conquista de um determinado fim, associando-se a um modelo teleológico ancorado em critérios identitários. Com efeito, Tonacci, nesse filme, ressaltamos, por não nomear nenhum de seus personagens, por duplicá-los, traçar neles características animalescas, travesti-los, desprovê-los de qualquer finalidade, os libera de uma visibilidade acovardada, vitimista, miserável ou impotente, em prol de uma reinvenção constante, ou seja, de uma visibilidade não aprisionada, mutável, imprevisível, em constante devir, que foge aos padrões e, por isso mesmo, inapreensível e irrepreensível, demonstrando a força do signo errático.

personagens; e espaço euclidiano se define como o meio no qual essas oposições se resolvem. Na narração do cinema clássico, segundo Deleuze, eles estão em complementaridade. No inorgânico essa complementaridade é quebrada, ou seja, não há relação de tensão e oposição que se resolva no espaço da narração, em decorrência da quebra nas relações de finalidade e de causa e efeito. 


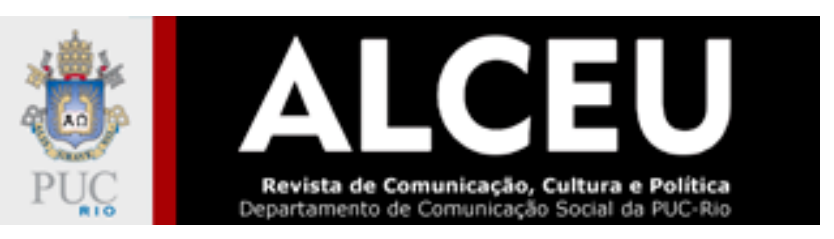

\section{O errático na deriva da narrativa}

A narrativa em Bang Bang se afirma pela ausência de uma lógica linear, explicativa e se apresenta de forma caótica. Utiliza-se do interstício entre as cenas, construídas de longos planos, de modo a quebrar a sua continuidade espaciotemporal. Desse modo, faz uso de imagens nômades, desterritorializadas, que não estabelecem continuidade de sentido com as que lhes antecedem ou sucedem. Além disso, usa de uma multiplicidade e heterogeneidade sígnica em suas cenas, que torna o filme insólito e assegura a sua inexplicabilidade.

Essa heterogeneidade sígnica se dá em cenas que pluralizam as situações óticas e sonoras, seja com interação entre os planos (primeiro plano e profundidade de campo), seja com o uso dos elementos audiovisuais em condições de não conformidade. Isso pode ser observado por volta dos $41 \mathrm{~min} 44 \mathrm{~s}$ do filme, numa cena de cerca de 08min de duração em que Pereio adentra um bar, no qual se encontra um bêbado no balcão e não há nenhum garçom para servi-los ou para atender ao telefone do local que toca, ininterruptamente. Enquanto o bêbado afirma repetidamente que ninguém irá aparecer, que Pereio deve pedir logo uma cerveja e um mictório, que tudo "está ótimo!", é possível observar também, pelo espelho à frente deles, tudo que se passa na rua, na parte externa desse lugar, de modo que num dado momento adentra ao espaço uma mulher. Pereio se volta ao encontro dela, inicia mais um diálogo que é reiniciado e repetido, buscando a forma ideal da conversação, ao tempo em que expressa pensamentos soltos, sem ligação aparente ao escopo da cena, demonstrando a erraticidade da própria conversa, que se dá ao som de uma música, de bombas, disparos de tiros e metralhadoras, do telefone que continua a tocar e, ainda, dos latidos de um cachorro. Há multiconversações nessa conversação, todavia nenhuma em consonância. $A$ cena finaliza com o trio de bandidos colados ao vidro do bar, do lado externo à mesa em que se encontra Pereio e a mulher, com ela dizendo-lhe que ele estava sendo óbvio demais. Aqui, Tonacci afina o absurdo cotidiano ao discurso irônico e imperturbável dos personagens, além de associá-lo a uma linguagem desterritorializada, que escapa ao escopo da cena.

Há, portanto, nessa cena, uma montagem irreverente e vertical, que se dá com uma interação dissimétrica entre os planos, haja vista que o que se passa no espelho em segundo plano não se correlaciona com o que acontece entre Pereio e o bêbado em primeiro; o que acontece no exterior do estabelecimento não coaduna ou vem para elucidar o que ocorre no seu interior. Além 


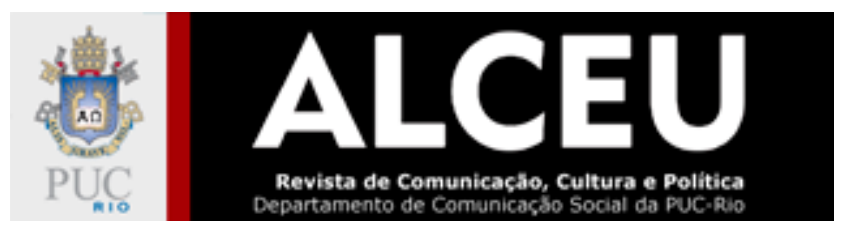

disso, há a disjunção entre os signos óticos e sonoros, com o saturamento destes últimos, que não estão em complementaridade, nem relação explicativa com os primeiros, mas reforçam uma atmosfera de perturbação, incômodo e estranhamento. Não há acorde harmônico em Bang Bang, mas um uso heterodoxo dos signos que corrobora para a ruptura com a narrativa sensório-motora e suas relações de causa e efeito, trazendo tons desencadeados e dissonantes tornam os opsignos e sonsignos como dois componentes autônomos da imagem. Em Bang Bang, consoante Deleuze aponta acerca do cinema moderno, a produção é realmente audiovisual e não busca a constituição de um todo fílmico dado:

O que constitui a imagem audiovisual é uma disjunção, uma dissociação do visual e do sonoro, ambos heutônomos, mas ao mesmo tempo uma relação incomensurável ou um 'irracional' que liga um ao outro, sem formarem um todo, sem se proporem o menor todo. É uma resistência oriunda do arruinamento do esquema sensório-motor, e que separa a imagem visual e a imagem sonora, mas integrando-as, mais ainda, numa relação não totalizável (DELEUZE, 2013, p. 303, grifos do autor).

Ainda conforme Deleuze (2013) acerca da imagem-tempo, ao utilizar dessa multiplicidade de signos óticos, sonoros, táteis, corpóreos e virtuais que abarcam heterogeneidade, Bang Bang abraça uma lógica plural, numa infinidade de combinações, constituindo uma variedade de sentidos que, enquanto acontecimentos, rompem com qualquer perspectiva de enquadramento representacional. Ademais, ao fazer uso da disjunção entre o ver e o falar, tem-se introduzido por esse cinema a noção de combate entre visibilidades e dizibilidades, realizando uma crítica à codificação da imagem muito bem demonstrada na junção entre o que é visto e o que é dito, presente nas estratificações e arquivos audiovisuais que compõem o jogo de verdade e de saberes que constituem uma determinada formação histórica. Dessa forma, Tonacci associa à operação de desconstrução narrativa uma inventividade não só estética, mas sobretudo política, na medida em que faz vibrar as imagens e retira a linguagem de sua herança representativa e informacional, cujo imperativo se dá na transmissão ordenatória de receituários, para alocá-la num exercício de resistência.

\section{A deriva estendida ao espectador}

Por meio desses descentramentos e multiplicidade sígnica, o filme suspende as condições de uma adesão completa a uma interpretação, causando no espectador um estranhamento e um 


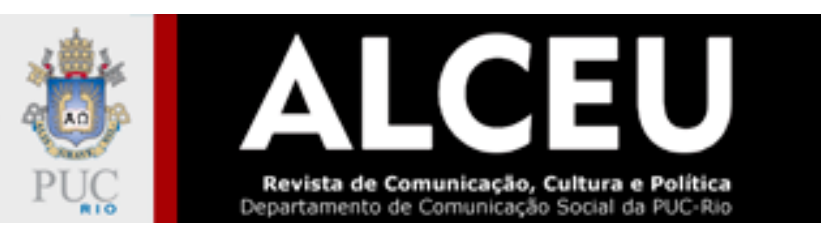

distanciamento que impede a construção de uma unidade de sentido capaz de promover uma eventual catarse. De modo diverso, obriga-o a problematizar a imagem, colocando o seu pensamento em movimento e deslocando os hábitos da sua retina. Dito de outro modo, ao se utilizar, numa mesma cena, de signos que seguem caminhos dissimétricos, aponta que nela há algo que é dito e algo que é visto, algo visto que pode ser lido e algo dito que pode ser visto, sem correspondência adequada ou acordada entre os dois, de modo a não realizar uma apropriação dos sentidos do espectador, naturalizando a percepção. Antes de conduzir o pensamento e a atenção do espectador para obter resultados preestabelecidos, provoca seu pensar por meio do desconcerto no olhar.

Aproximando-nos do que aponta Schöpke (2012) acerca do pensamento deleuziano, compreendemos que, por se tratar de uma arte nômade, de modo homólogo às demais análises de Deleuze acerca de outras obras, sejam literárias ou cinematográficas, também Bang Bang "causa uma espécie de mal-estar e uma desagradável sensação de ignorância àqueles que tentam decifrá-la segundo códigos do mundo sedentário" (p. 179), pois trabalha com forças de fora que impedem qualquer fixação de parâmetros. Desta feita, conforme já apontamos, faz devires com todos os personagens: devir-mulher e devir-animal, em seu longo caminho no espaço liso, sem cair em formas rígidas, criando zonas de vizinhança, e se mostrando inacabado. Logo, longe de representar forças sedentárias em seu enredo, tais como histórias de amor, viagens, dramas, enfim, sonhos próprios do espaço estriado das regras morais e sociais, se dirige a outra tribo, de forças nômades e fluídas, só compreendidas para quem se habilita a derivar junto, no mesmo barco. É preciso devir-Tonacci para experimentar e compreender Bang Bang.

Ao final, Bang Bang ainda ri do espectador, debocha de todo seu esforço em tentar juntar suas peças durante cerca de 1 h30min, como se o filme fosse um quebra-cabeças. Não o é. Tonacci cria o seu real, associando a experiência do desconforto ao irônico, apontando para a possibilidade do pensamento se fazer no errático, sem garantias, de modo alegre, escrachado e divertido.

\section{O errático na deriva temporal}

Bang Bang, embora composto de uma diegese anárquica, consegue mobilizar seus personagens numa relação temporal complexa e capaz de associar a diferença à repetição, por meio, inclusive, de atitudes compulsivas nas cenas. Isso fica exposto no gesto do bandido travesti 


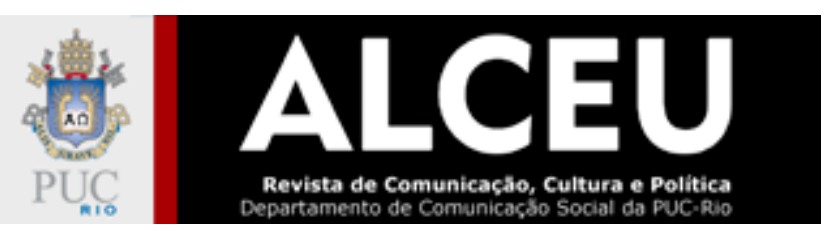

sempre comendo, numa mastigação compulsiva e repulsiva, durante todo filme. As cenas também são integralmente retomadas, mas de modo diferencial, apontado na sutiliza dos encontros e dos diálogos e na reação dos atores, conforme se observa na duplicação da cena inicial do filme, com a corrida de táxi de Pereio, reapresentada aos 37min09s do filme. Essa repetição da diferença estabelece uma relação singular com o tempo, mostrando o passado não como modelo ou origem, que poderia esvaziar o sentido do repetido, mas como afirmação do que difere, demonstrando uma potência do simulacro em criar o novo.

O filme também sinaliza recomeços ao se utilizar dos mesmos atores para mais de um enredo e personagem, de modo a apontar novas possibilidades aos próprios personagens. Todavia, embora outros, noutros espaços ou com novas performances, nada no filme os faz avançar ou efetivar suas ações num estado de coisas, permanecendo o caráter inconcluso da obra. Com personagens inominados, cada nova ancoragem é fugidia e relança para novos mundos, que trazem afetos diferentes e causam novas sensações, impossibilitando o fechamento dramático capaz de religar o passado ao futuro. Qual o destino final? Pouco importa, pois num filme errático, parafraseando Xavier (2012) mais vale o processo do que o produto. Desta feita, o filme se esquiva de um tempo cronologicamente retilíneo e ordenado socialmente, para se mostrar, nessa transformação, enquanto o próprio acontecimento que relata, acolhendo passagens e simultaneidades.

Ademais, cada uma das cenas de Bang Bang traz um modo singular de lidar com o tempo que corrobora com a desconstrução da narrativa na medida em que expõe um ritmo ora lento (conforme a cena final do filme em que Pereio faz a barba e troca de roupa enquanto cantarola uma valsa), ora embriagante (durante a belíssima cena em que a dançarina faz sua performance no alto de um edifício), ora frenético (conforme a cena que apresenta um mágico realizando truques que alteram rapidamente o cenário fílmico com o estalar de dedos, trancafiado num quarto espelhado, junto aos bandidos, que lá também se metamorfoseiam), desorganizando a atenção perceptiva e o afeto do espectador, que ora se vê entediado, ora envolvido, ora desconfortante.

$\mathrm{O}$ uso das imagens espelhadas são uma constante no filme e, associadas a uma montagem que imbrica o contínuo e o descontínuo, promove um devaneio visual, num jogo plástico e experiencial entre o espaço e o tempo que cria modulações na imagem e se esquiva das linhas duras (moldes) da montagem clássica. Essa cena do truque de mágica, por exemplo, é marcada pelo espaço do quarto, mas realizada com uma montagem histérica e descontínua, que causa 


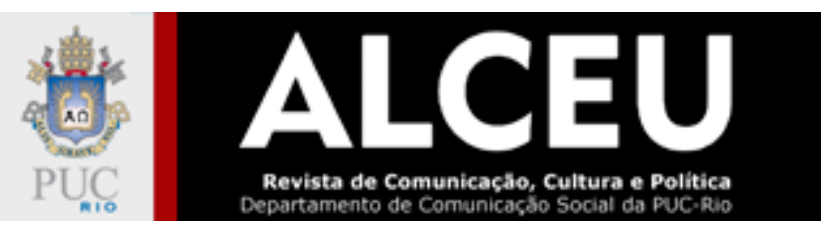

vertigem. Inicia-se com um mágico sentado à cama de um quarto arrumado de hotel (o mesmo da cena em que o homem-macaco transa com a mulher), ao som da música de abertura da Twentieth Century Fox, e é o estalar dos dedos desse mágico surpreso que monta o cenário, insere neles os personagens, altera a musicalidade, conduz toda a transformação da cena, desorganizando todo 0 ambiente que finaliza repleto de lixo no chão. Por outro lado, noutras cenas quase sempre desprovidas de edição, mas também de longa duração, a perdição visual do espectador vai se dar por meio da possibilidade que lhe é facultada de observar toda mise-en-scène, ou seja, Tonacci, aqui, além de proporcionar a observação do que o personagem mostra, dá a ver o que o cenário mostra, espelhando também a organização das suas locações, outra forma de lidar com o tempo como recurso dramático, sem subordiná-lo ao movimento. Assim, por meio da relação espaciotemporal, reforçamos, o filme constrói suas paisagens atento às experiências proporcionadas ao olhar, contudo buscando desnaturalizar a percepção e desencadear processos de desafetação, isto é, exerce um esforço de retirar da sensibilidade sua base interesseira e pragmática (DELEUZE, 2016).

Sobre este aspecto, inobstante se utilizar da montagem paralela para constituir várias histórias ao mesmo tempo, no interior do mesmo todo, impossibilita qualquer realização de convergência por similitude entre elas, já que não atualiza nenhum passado, nem aponta a nenhum futuro desfecho previsível, deixando claro que o filme não retrata pontos de vista diferentes sobre um mesmo aspecto, mas apresenta "histórias diferentes e divergentes, como se uma paisagem absolutamente distinta correspondesse a cada ponto de vista" (DELEUZE, 2015, p. 266), conforme bem pontuado aos dez últimos minutos de filme, quando o bandido travesti guloso, chupando laranja e cuspindo o bagaço, tenta doar ao filme uma possível explicação e tem-Ihe arremessado uma pizza, que o interrompe. Ele retorna ao carro, coçando as nádegas seguro a um barril de vinho e se lança novamente em movimento na estrada. Vejamos sua fala:

Era uma vez três bandidos... diziam que um deles era a mãe dos outros, mas não se sabe nada sobre isso... todos eram muito maus, a mãe, então, nem se fala... inclusive não sabe nada sobre isso... péssimos... roubavam tudo, matavam todo mundo, comiam tudo, quebravam tudo... até um dia em que roubaram... (TONACCI, 1971).

Com isso, negando qualquer possibilidade de atualização explicativa, Tonacci retira do presente o parâmetro de direção e convida a partilhar com ele das excitações dos sentidos, 


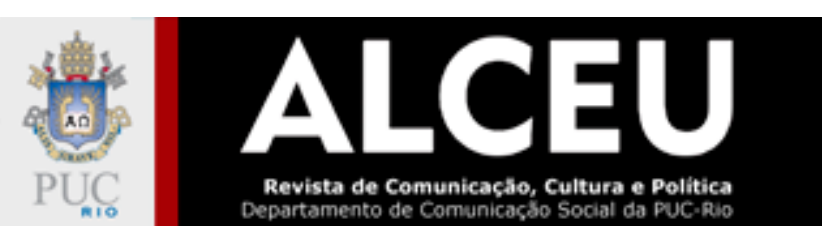

provocados pela deriva do pensamento enunciada em sua película que, próximo ao que Blanchot (2005, p. 13) compreende de Moby Dick, traz "o tempo das metamorfoses em que coincidem, numa simultaneidade imaginária e sob a forma do espaço que a arte busca realizar, as diferentes estases temporais".

\section{O errático na ingestão antropofágica de Bang Bang: A digestão nômade tonacciana e a construção singular do seu cinema menor}

Guéron (2016), nos informa que os cineastas do cinema marginal brasileiro, assim como os artistas do movimento modernista brasileiro, Mario e Oswald de Andrade, concebiam possível a criação de algo inovador a partir da ingestão e digestão antropofágica de outras culturas, sem a busca obsessiva por uma originalidade pura, se apresentando "ao mesmo tempo liquidificador alucinado e máquina reprocessadora de clichês" (p. 209), ou seja, engolindo e processando o cinema da indústria cultural hollywoodiana em vigor, mas dobrando e expandindo sua força por meio da sua singularidade. Essa leitura nos interessa em Bang Bang por corroborar com a operação de Tonacci em se lançar na dimensão da linha de fuga dos padrões estabelecidos e instaurar, de forma insólita, uma micropolítica capaz de fissurar o senso-comum de modelos pré-estabelecidos e propor novos encontros, de modo a construir de forma singular seu cinema-menor.

Desta feita, Tonacci em Bang Bang, traz uma série de referências a gêneros, categorias e movimentos cinematográficos, tais como: comédia, policial, noir, surrealismo, com representações típicas das perseguições, passeios em família, uso do automóvel conversível dos embalos de sábado à noite, mas sem se prender a nenhum deles, se mostrando também por isso como um diretor nômade. Antes, subverte-os, sabota-os, ironiza-os, mas com extremado cuidado e sutileza, fazendo um uso paradoxal e espetacular de suas técnicas, num esforço de discussão metacinematográfica.

Consoante aponta Xavier (2012), tendo como mote central e mais claro o filme policial americano, Bang Bang incorpora clichês da imagem-ação, todavia os avacalha, de modo que, apesar de figurar num espaço urbano com personagens típicos (como os gangster), não tem sequer a perseguição como tema central do seu enredo, haja vista que mesmo esta é falseada, sem origem, nem fim, atrapalhada, que atira pra qualquer lado, servindo mais a um convite, para uma discussão em torno do modo mesmo de fazer cinema. Destarte, salienta Xavier, se, por um lado, 
Bang Bang em seus primeiros 30min se utiliza da perseguição vertical, na cidade, em seus prédios e elevadores, é para através dela expor também as condições de realização de suas tomadas, deixando refletir no jogo de espelhos seu equipamento de filmagem. Por outro lado, mais ao final do filme, o tema da perseguição é apresentado de modo horizontalizado, na estrada, campo exterior à cidade, numa corrida de carro que, por sua vez, também reflete a posição da câmera por meio da sua sombra, deflagrando aí também um corte com a narrativa clássica da transparência e instituindo a opacidade como sua marca ${ }^{9}$.

A exposição do dispositivo utilizado na feitura da obra, bem como a apresentação da sua equipe de filmagem, rompe com os limites da tela e deixa claro ao espectador, ademais, que o filme se trata de uma produção e não de um espetáculo representativo do real e, por ser arte criadora, se mostra mais capaz de reverter e transvalorar para além de uma imagem maior, eleita enquanto pretendente, uniformizadora e generalizante. Com isso, Bang Bang se esquiva da grande e da pequena forma da imagem-ação ${ }^{10}$ que possui função verídica e moral, ainda que na ficção, haja vista não buscar elucidar e transformar a situação ou ação inicial a partir de um personagem e enredo centrais, vitalizando com o menor apresentado com a multiplicidade dos signos, com a fragmentação do espaço, com a errância e mutabilidade das personagens, com sua montagem vertiginosa e seus movimentos aberrantes, que conjura a forma do verdadeiro e da unidade construída em torno do herói ou de uma salvação possível.

\section{Conclusão: um cinema menor para um pensamento do fora}

Com tais impressões, Tonacci nos presenteia com um filme de encontros fragmentados, composto com imagens óticas e sonoras plenas de signos cinematográficos provocativos, rompendo com a unidade narrativa, numa espécie de deboche com as imagens que encenam uma diegese orgânica e comportamental. Com isso, provoca um desconcerto no olhar, através de um saturamento ótico e sonoro, que rompe com os limites da tela e traz efeitos diversos, por meio de uma heterogeneidade na forma e no conteúdo capaz de inserir um mal-estar, deslocando-nos e deixando-nos à deriva. De tal modo, Tonacci estende, portanto, a nós, as experimentações contidas

\footnotetext{
${ }^{9}$ Sobre o desenvolvimento dos recursos de opacidade e transparência na sétima arte, verificar a obra do Ismail Xavier $O$ discurso cinematográfico: opacidade e transparência. Na obra Alegorias do Subdesenvolvimento, no capítulo intitulado "Bang Bang: alegoria e ironia", ele trabalha essas questões referentes ao filme aqui analisado.

10 Deleuze discorre sobre a grande e a pequena forma da imagem-ação nos capítulos 9 e 10 da obra A Imagem-Movimento (1983).
} 


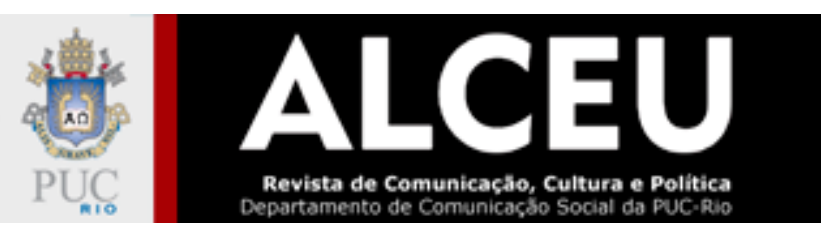

em sua própria película, que retrata também um filme à deriva, ou seja, que está sempre no meio, sem destinação específica, impossibilitando, com isso, qualquer perspectiva teleológica de interpretação de suas imagens, apresentando o pensamento enquanto incerto e errante, que se constrói num caminho experiencial e tateante.

Portanto, ao acompanhar os devires constantes em Bang Bang adentrando suas linhas heterogêneas e mutáveis, foi-nos possível perceber que: na expressão do indefinido, na apresentação caótica dos signos cinematográficos, na afetação de ordem experimental, Bang Bang se coloca na experiência sensível do deslocamento e, se alimentando da sua própria força metamórfica, foge de toda tentativa dura de ancoragem e se interessa muito mais pelos fluxos, ou seja, por aquilo que o tempo todo se desconstrói para em seguida se reconstruir. Cumpre acrescentar que, ao trazer a desconstrução do gênero cinematográfico americano na contrapartida dessa experimentação construída nas derivas acima descritas, Bang Bang se faz, ainda, como dissemos, como um filme menor: é menor no procedimento revolucionário de evocação de um povo minoritário, de um povo que falta nos espaços nômades da cidade e na exposição, sem espetáculo, das perambulações de um protagonista errante filmado ao longo de sequências díspares e aberrantes.

Com competência fílmica e rigor na apresentação das ideias por intermédio de um singular pensamento cinematográfico, o filme faz pensar pelas experimentações que apresenta ao espectador no campo entreaberto pelos planos-sequências filmados em duração real. No intercurso audiovisual consistido por imagens óticas e sonoras puras, Tonacci evoca um espaço nômade na cidade supostamente estriada de Belo Horizonte. Assim, ele explora o fora de Belo Horizonte nos espaços nômades da cidade, fazendo dos movimentos erráticos os disparadores de questões que forçam o espectador a pensar na vida e no mundo no qual os humanos circulam. Por tais motivos, os movimentos erráticos de Bang Bang, são a expressão cabal de uma experiência do fora no cinema voltado para uma desconstrução revolucionária da realidade, das convenções morais, sem objetivar fazer do espectador um militante e sem cair na nulidade abstrativa. São todas essas condições que fazem desse filme um filme além de errático, nômade e atemporal.

Auterives Maciel Júnior Doutor em Teoria Psicanalítica pela UFRJ Docente Adjunto na UVA-RJ e Docente na PUC-RJ ORCID: https://orcid.org/0000-0002-8221-1105 E-mail: autermaciel@gmail.com 
Doutoranda em Memória: Linguagem e Sociedade, UESB-BA; Bolsista FAPESB ORCID: https://orcid.org/0000-0001-7927-8635

E-mail: asgavila@gmail.com

Recebido em: 12 de junho de 2019.

Aprovado em: 01 de setembro de 2019.

\section{Referências}

BLANCHOT, Maurice. O livro por vir. São Paulo: Martins Fontes, 2005.

DELEUZE, Gilles. A Imagem-movimento (Cinema 1). Lisboa: Assírio \& Alvim, 2009.

A Imagem-tempo (Cinema 2). São Paulo: Brasiliense, 2013.

1988.

Diferença e repetição. Tradução de Luiz Orlandi e Roberto Machado. Rio de Janeiro: Graal,

Dois Regimes de Loucos (textos e entrevistas 1975-1995). Edição preparada por David Lapoujade. São Paulo: Editora 34, 2016.

Kafka: Por uma literatura menor. Belo Horizonte: Autêntica Editora, 2014.

. Lógica do Sentido. São Paulo: Perspectiva, 2015.

Mil Platôs. Vol. 5. São Paulo: Editora 34, 1997.

. Sobre o Teatro: um manifesto de menos; o esgotado. Rio de Janeiro: Zahar, 2010.

; GUATTARI, Felix. Mil Platôs. Vol. 3. São Paulo: Editora 34, 2012.

FOUCAULT, Michel. El Pensamiento del Afuera. Valencia: Pré-Textos, 1988.

GUERON, Rodrigo. O trágico e o antropofágico nas imagens colonizadas. Revista Passages de Paris. № $12 / 2016$ (p. 189-213). Disponível em: http://apebfr.org/passagesdeparis/editione2016vol1/articles/pdf/PP12 Dossier7.pdf. Acessado em: 09/01/2018.

LAPOUJADE, David. Deleuze, os movimentos aberrantes. São Paulo: n-1 edições, 2015.

NIETZSCHE, Friedrich. Crepúsculo dos Ídolos. São Paulo: Cia das Letras, 2006.

SCHOPKE, Regina. Por uma filosofia da diferença: Gilles Deleuze, o pensador nômade. Rio de Janeiro: Contraponto, 2012.

TONACCI, Andrea. Bang Bang. São Paulo: 1971, 81 min. 35mm, p\&b. Direção e Roteiro: Andrea Tonacci. Fotografia: Thiago Veloso. Montagem: Roman Stulbach. Cenografia: Andrea Tonacci e Milton Gontijo. 


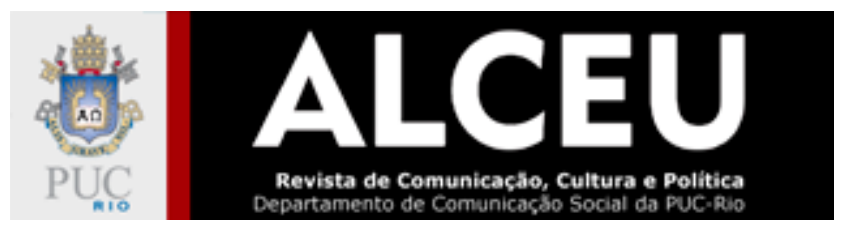

Produção Executiva: Luis Carlos Pires. Elenco: Paulo Cesar Pereio, Jura Otero, Abraão Farc, Ezequias Marques, José Aurélio Vieira, Antonio Naddeo, Milton Gontijo, Thales Penna. Produtora: Total Filmes.

XAVIER, Ismail. Alegorias do subdesenvolvimento: cinema novo, tropicalismo e cinema marginal. São Paulo: Cosac Naify, 2012.

O discurso cinematográfico: opacidade e transparência. São Paulo: Paz e Terra, 2014.

\title{
Resumo
}

A nossa proposta é articular dois campos de produção de saber, quais sejam a filosofia e o cinema numa problematização da experiência do pensar. Desse modo, tendo como interlocutores o cineasta Andrea Tonacci com o filme Bang Bang (1971) e os filósofos Gilles Deleuze e Felix Guattari, buscaremos, em primeiro lugar, nomear um modo de pensar que compreendemos engendrado pelos movimentos erráticos fílmicos, como um pensamento experimental efetuado na ruptura com a realidade determinada; em seguida, definiremos tal procedimento fílmico por intermédio daquilo que aqui conceituaremos como um "cinema menor". Com a explicitação destas duas questões, construiremos a argumentação explicativa das derivas fílmicas tonaccianas, de modo a mostrá-las enquanto uma força de problematização radical e construção revolucionária da realidade.

Palavras-chave: Andrea Tonacci; Cinema Menor; movimentos erráticos.

\begin{abstract}
Our proposal is to articulate two fields of knowledge production, namely philosophy and cinema, in a problematization of the experience of thinking. Thus, having as interlocutors the filmmaker Andrea Tonacci with the film Bang Bang (1971) and the philosophers Gilles Deleuze and Felix Guattari, first we will seek to appoint a way of thinking that we understand engendered by the erratics movements of the film, as an experimental thought that is done in the rupture with the determined reality; Then we will define filmic procedures for what we're going to conceptuate as a "minor cinema". With the explanation of these two questions, we will construct the explanatory argumentation of the Tonaccian film, to show their strength of radical problematization and of revolutionary construction of reality.
\end{abstract}

Keywords: Andrea Tonacci; minor cinema; erratic movements.

\section{Resumen}

Nuestra propuesta es articular dos campos de producción de conocimiento, filosofía y cine, en una problematización de la experiencia del pensar. Así, teniendo como interlocutores el cineasta Andrea Tonacci con la película Bang Bang (1971) y los filósofos Gilles Deleuze y Felix Guattari, primero intentaremos designar una forma de pensar que comprendamos engendrada por los movimientos erráticos de la película, como un pensamiento experimental que se realiza cuando se rompe con la realidad determinada; Despues definiremos los procedimientos fílmicos como un "cine menor". Con la explicación de estas dos preguntas, construiremos la argumentación explicativa de la película tonacciana, para mostrar su fuerza de problematización radical y de construcción revolucionaria de la realidad.

Palabras clave: Andrea Tonacci; “cine menor”; movimientos erráticos 